Article

\title{
Antiviral Effects of Houttuynia cordata Polysaccharide Extract on Murine Norovirus-1 (MNV-1)-A Human Norovirus Surrogate
}

\author{
Dongqing Cheng ${ }^{1,2,+}$, Liang Sun ${ }^{1,+}$, Songyan Zou ${ }^{2}$, Jiang Chen ${ }^{1}$, Haiyan Mao ${ }^{1}$, Yanjun Zhang ${ }^{1}$, \\ Ningbo Liao ${ }^{1,3, *}$ and Ronghua Zhang ${ }^{1,2, *}$ \\ 1 Department of Nutrition and Food Safety, Zhejiang Provincial Center for Disease Control and Prevention, \\ Hangzhou 310006, China; chengdq@zcmu.edu.cn (D.C.); lsun@cdc.zj.cn (L.S.); jchen@cdc.zj.cn (J.C.); \\ hymao@cdc.zj.cn (H.M.); yjzhang@cdc.zj.cn (Y.Z.) \\ 2 College of Medical Technology, Zhejiang Chinese Medical University, Hangzhou 310053, China; \\ zou_songyan@126.com \\ 3 School of Public Health, Division of Infectious Diseases and Vaccinology, University of California, \\ Berkeley, CA 94720, USA \\ * Correspondence: liaoningbo2010@126.com (N.L.); rhzhang@cdc.zj.cn (R.Z.); \\ Tel./Fax: +86-571-87115140 (N.L.); Tel./Fax: +86-571-87115214 (R.Z.) \\ + These authors contributed equally to this work.
}

Academic Editors: Cédric Delattre and Raphaël E. Duval

Received: 4 March 2019; Accepted: 9 May 2019; Published: 13 May 2019

check for updates

\begin{abstract}
Houttuynia cordata is an herbal plant rich in polysaccharides and with several pharmacological activities. Human noroviruses (HuNoVs) are the most common cause of foodborne viral gastroenteritis throughout the world. In this study, H. cordata polysaccharide (HP), with a molecular weight of $\sim 43 \mathrm{kDa}$, was purified from $H$. cordata water extract (HWE). The polysaccharide HP was composed predominantly of galacturonic acid, galactose, glucose, and xylose in a molar ratio of 1.56:1.49:1.26:1.11. Methylation and NMR analyses revealed that HP was a pectin-like acidic polysaccharide mainly consisting of $\alpha$-1,4-linked Gal $p$ A, $\beta-1,4$-linked Gal $p, \beta-1,4$-linked Glc $p$, and $\beta$-1,4-linked Xyl $p$ residues. To evaluate the antiviral activity of $H$. cordata extracts, we compared the anti-norovirus potential of HP with HWE and ethanol extract (HEE) from $H$. cordata by plaque assay (plaque forming units $(\mathrm{PFU}) / \mathrm{mL}$ ) for murine norovirus-1 (MNV-1), a surrogate of HuNoVs. Viruses at high (8.09 $\log 10 \mathrm{PFU} / \mathrm{mL})$ or $\operatorname{low}(4.38 \log 10 \mathrm{PFU} / \mathrm{mL})$ counts were mixed with 100, 250, and $500 \mu \mathrm{g} / \mathrm{mL}$ of HP, HWE or HEE and incubated for $30 \mathrm{~min}$ at room temperature. H. cordata polysaccharide (HP) was more effective than HEE in reducing MNV-1 plaque formation, but less effective than HWE. When MNV-1 was treated with $500 \mu \mathrm{g} / \mathrm{mL} \mathrm{HP}$, the infectivity of MNV-1 decreased to an undetectable level. The selectivity indexes of each sample were 1.95 for HEE, 5.74 for HP, and 16.14 for HWE. The results of decimal reduction time and transmission electron microscopic revealed that HP has anti-viral effects by deforming and inflating virus particles, thereby inhibiting the penetration of viruses in target cells. These findings suggest that HP might have potential as an antiviral agent in the treatment of viral diseases.
\end{abstract}

Keywords: antiviral effects; Houttuynia cordata; polysaccharide; water extract; ethanol extract; murine norovirus-1

\section{Introduction}

Houttuynia cordata Thunb. is a medicinal plant commonly found in Southeast Asia. In China, the young roots and green leaves of $H$. cordata are popular vegetable products, being used in the preparation of beverages by boiling decoction. Houttuynia cordata contains a wide range of compounds including polysaccharides, fatty acids, polyphenols, flavonoids, and sterols, and has anti-viral, 
antifungal, detoxifying, and anti-bacterial properties [1]. Hayashi et al. [2] reported that $H$. cordata extract reduces the infectivity (by $>4 \mathrm{log}$ ) of several viruses, including the influenza virus and HIV. Even though several biological activities of $H$. cordata have been studied [3], the effects of $H$. cordata against human noroviruses (HuNoVs) and its mechanism of action remain unknown.

Human noroviruses, which belong to the Caliciviridae family, are the most common cause of foodborne viral gastroenteritis throughout the world. Human noroviruses can be divided into five major genogroups, genogroup I (GI) through genogroup V (GV); Genogroup II.4 (GII.4) HuNoVs are closely related to most foodborne noroviral outbreaks. Human noroviruses infections mainly occur via person-to-person transmission through fecal-oral route or by consuming contaminated food. Human noroviruses are highly tolerant to environmental changes and have low infectious doses of eight to 10 viral particles [4]. Most sources of foodborne disease caused by HuNoVs are foods prepared with contaminated hands or cookware. Currently, there is no commercially available antiviral drug or vaccine for the prevention of norovirus infections or outbreaks.

The inactivation of HuNoVs mainly relies on physical treatments including chemical methods (e.g., titanium dioxide, sodium hypochlorite, and hydrogen peroxide), heat treatment, and ultraviolet radiation. However, the use of such treatments is frequently inadequate in the food industry. Therefore, it is of utmost importance to investigate safe anti-noroviral agents that can be consumed. Several compounds isolated from plants (e.g., polysaccharides, polyphenols, and flavonoids) have antimicrobial activity [5]. A recent review suggested that plant extracts containing polysaccharides and polyphenols, such as Ganoderma lucidum polysaccharide (GLPS), Pericarpium granati extract (PGE), and Pomegranate extract (PE), might prevent infection from NoV surrogates [6]. These natural products are safe antiviral agents because they can be eaten, and their nutrition-promoting properties have long been studied $[7,8]$.

Even though it has been reported that HuNoVs may be cultured in B cells in vitro, there are several disadvantages to this method for screening natural antiviral compounds [4]. Anti-noroviral effects are evaluated from the reduction in infectivity of cultivatable HuNoV surrogates such as murine norovirus (MNV-1), bacteriophage MS2, or other in vitro models of HuNoV infectivity detection (in situ capture qRT-PCR) [9-11]. Among them, MNV-1, a genogroup V (GV) cultivable norovirus, is currently recognized as the most suitable surrogate for HuNoVs [10].

In the study, we identified the anti-norovirus potential of crude water extract (HWE), purified polysaccharide (HP), and ethanol extract (HEE) from H. cordata by plaque assay for MNV-1. Additionally, we investigated the structure, chemical composition, and antiviral mechanism of HP.

\section{Results}

\subsection{Chemical Analyses of HP, HWE, and HEE}

Extraction yields of $\mathrm{HP}, \mathrm{HWE}$, and HEE from $H$. cordata were $5.7 \%, 16.3 \%$, and $9.6 \%$, respectively. The chemical compositions of the extracts are shown in Table 1. Ethanol extract samples contained $25.42 \pm 2.31$ gallic acid equivalents (GAE)/mg total phenolic, $19.76 \pm 3.73$ retinol equivalent $(\mathrm{RE}) / \mathrm{mg}$ total flavonoid, and $2.37 \pm 1.45 \%$ neutral sugars. Crude water extract samples contained $14.59 \pm 2.41 \mathrm{GAE} / \mathrm{mg}$ total phenolic, $10.62 \pm 1.43 \mathrm{RE} / \mathrm{mg}$ total flavonoid, $25.67 \pm 1.97 \%$ neutral sugars, and $12.34 \pm 2.01 \%$ uronic acids. Compared to HEE, HWE contained more carbohydrate. The total carbohydrate content (38.01\%) of HWE was calculated by adding neutral sugar and uronic acid values. Purified polysaccharide was isolated from HWE. The HPLC profile of HP revealed a single peak with a molecular weight (Mw) of $43 \mathrm{kDa}$. The total carbohydrate content of HP was $81.12 \%$. Monosaccharides in HP were mainly galacturonic acid (GlaUA), xylose (Xyl), glucose (Glc), and galactose (Gal). Minor amounts of glucuronic acid (GlcUA), arabinose (Ara), mannose (Man), and rhamnose (Rha) were obtained. The protein content of HP was $0.89 \%$. The sugar composition of HP was similar to the H. cordata polysaccharide fractions (HCP and HCP-2) reported in past studies $[12,13]$. 
Table 1. Yields and chemical composition of Houttuynia cordata extracts HP, HWE, and HEE ${ }^{\text {a }}$

\begin{tabular}{|c|c|c|c|}
\hline \multirow{2}{*}{ Composition $^{b}$} & \multicolumn{3}{|c|}{ Extract/Fraction } \\
\hline & HP & HWE & HEE \\
\hline Extraction yield (\%) & $5.73 \pm 2.16$ & $16.31 \pm 1.64$ & $9.63 \pm 2.31$ \\
\hline Total phenolic ( $\mu \mathrm{g}$ GAE/mg) & $\mathrm{ND}^{\mathrm{c}}$ & $14.59 \pm 2.41$ & $25.42 \pm 3.17$ \\
\hline Total flavonoid ( $\mu \mathrm{g} \mathrm{RE} / \mathrm{mg}$ ) & ND & $10.62 \pm 1.43$ & $19.76 \pm 3.73$ \\
\hline Protein $(\%)$ & $0.89 \pm 0.12$ & $2.54 \pm 0.12$ & $5.68 \pm 1.76$ \\
\hline Total carbohydrate $(\%)$ & $81.12 \pm 5.98$ & $38.01 \pm 3.98$ & $2.37 \pm 1.45$ \\
\hline Neutral sugars (\%) & $56.33 \pm 4.37$ & $26.58 \pm 2.54$ & $2.37 \pm 1.45$ \\
\hline Uronic acid (\%) & $23.77 \pm 3.42$ & $12.34 \pm 2.13$ & ND \\
\hline \multicolumn{4}{|c|}{ Molar ratio of monosaccharides ${ }^{\mathrm{d}}$} \\
\hline GlaUA & 1.56 & 1.37 & ND \\
\hline Gal & 1.49 & 0.94 & ND \\
\hline Rha & 0.83 & ND & ND \\
\hline Ara & 0.68 & ND & ND \\
\hline GluA & 0.31 & ND & ND \\
\hline Glc & 1.26 & 0.31 & ND \\
\hline Man & 0.14 & ND & ND \\
\hline $\mathrm{Xyl}$ & 1.11 & ND & ND \\
\hline
\end{tabular}

a HP, Houttuynia cordata polysaccharide; HWE, Houttuynia cordata water extract; HEE, Houttuynia cordata ethanol extract. ${ }^{b}$ GAE, gallic acid equivalents; RE, retinol equivalent. ${ }^{c}$ Not detected. ${ }^{d}$ GlaUA, galacturonic acid; Gal, galactose; Rha, rhamnose; Ara, arabinose; GluA, glucuronic acid; Glc, glucose; Man, mannose; Xyl, xylose.

The IR spectrum of HP from H. cordata is shown in Figure 1. The band at $3406.0 \mathrm{~cm}^{-1}$ is attributed to $\mathrm{O}-\mathrm{H}$ or $\mathrm{N}-\mathrm{H}$ stretching vibration. The band at $2931.3 \mathrm{~cm}^{-1}$ is attributed to $\mathrm{sp}^{3} \mathrm{C}-\mathrm{H}$. The peak at $1644.8 \mathrm{~cm}^{-1}$ might be due to amide $\mathrm{C}=\mathrm{O}$ stretching vibration and/or $\mathrm{C}=\mathrm{C}$ stretching vibration and/or N-H [14]. The bands at 1644.8 and $1403.0 \mathrm{~cm}^{-1}$ are attributed to the presence of proteins in HP. Moreover, the characteristic absorption at $1200-1000 \mathrm{~cm}^{-1}$ is attributed to the presence of glycosidic linkages $\mathrm{C}-\mathrm{O}$ and/or $\mathrm{C}-\mathrm{N}$ in $\mathrm{HP}$ [15]. All these results suggest that $\mathrm{HP}$ is an acidic polysaccharide.

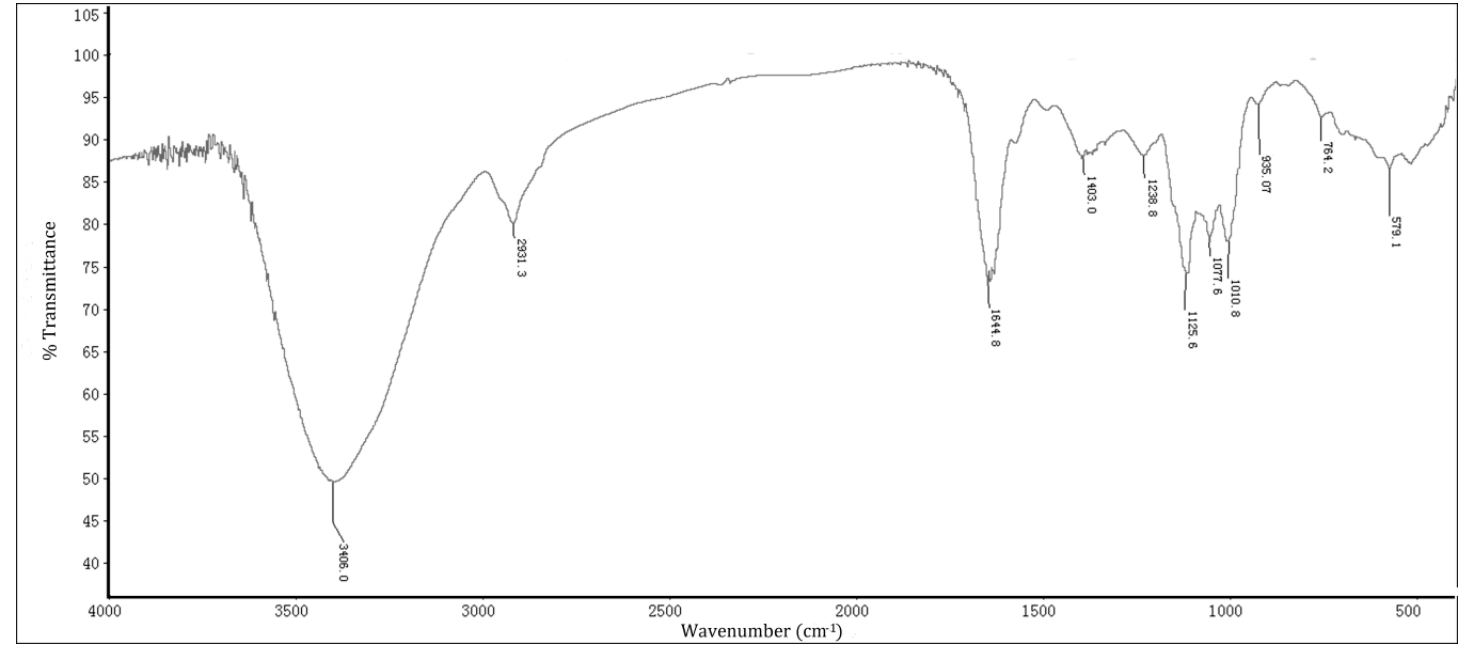

Figure 1. FTIR spectra of HP in the frequency range $4000-500 \mathrm{~cm}^{-1}$.

The methylation analysis results of HP are summarized in Table 2. The polysaccharide HP mainly consisted of 1,4-linked GalpA, 1,4-linked Galp, 1,4-linked Glcp, and 1,4-linked Xylp residues in a molar ratio of 1.74:0.93:0.95:0.84. The high prevalence of Galp and GalpA residues revealed that HP might be a pectin-like acidic polysaccharide with a 1,4-linked Galp core. In addition, other small proportions of residues 1,5-linked Araf, 1,2,4-linked Rhap, 1,6-linked Galp, 1,4,6-linked Galp, and terminal-linked Gal $p$ and Glc $p$, which have been reported in the side chains, were detected.

Table 2. Methylation analysis of Houttuynia cordata polysaccharide HP.

\begin{tabular}{|c|c|c|c|}
\hline Sugar ${ }^{a}$ & Partially $O$-methylated Alditol Acetates & Molar Ratio & Linkage $^{d}$ \\
\hline GalpA & $2,3,6-\mathrm{Me}_{3} \mathrm{Gal}-6-\mathrm{d}_{2}{ }^{\mathrm{b}}$ & 1.74 & $\rightarrow 4)-$ Gal $p$ A- $(1 \rightarrow$ \\
\hline \multirow[t]{2}{*}{ Galp } & $2,3,6-\mathrm{Me}_{3} \mathrm{Gal}$ & 0.93 & $\rightarrow 4)$-Gal $p-(1 \rightarrow$ \\
\hline & $2,3,4-\mathrm{Me}_{3} \mathrm{Gal}$ & 0.14 & $\rightarrow 6)$-Galp-(1 $\rightarrow$ \\
\hline
\end{tabular}


Table 2. Cont

\begin{tabular}{|c|c|c|c|}
\hline Sugar $^{a}$ & Partially $O$-methylated Alditol Acetates & Molar Ratio & Linkage $^{d}$ \\
\hline \multirow{4}{*}{ Glcp } & 2,3-Me $2 \mathrm{Gal}$ & 0.21 & $\rightarrow 4,6)-$ Gal $p-(1 \rightarrow$ \\
\hline & $2,3,4,6-\mathrm{Me}_{4} \mathrm{Gal}$ & 0.35 & Gal $p-(1 \rightarrow$ \\
\hline & $2,3,6-\mathrm{Me}_{3} \mathrm{Glc}$ & 0.95 & $\rightarrow 4)$-Glc $p$ - $(1 \rightarrow$ \\
\hline & $2,3,4,6-\mathrm{Me}_{4} \mathrm{Glc}^{\mathrm{c}}$ & 0.37 & Glcp- $(1 \rightarrow$ \\
\hline $\mathrm{Xyl} p$ & 2,3-Me 2 Xyl & 0.84 & $\rightarrow 4)-\mathrm{Xyl} p-(1 \rightarrow$ \\
\hline Rhap & 3-Me Rha & 0.22 & $\rightarrow 2,4)$-Rhap-(1 $\rightarrow$ \\
\hline Araf & 2,3- $-\mathrm{Me}_{2}$ Ara & 0.17 & $\rightarrow 5)$-Araf-(1 $\rightarrow$ \\
\hline
\end{tabular}

a Gal $p$ A, galactopyranosyluronic acid; Gal $p$, galactopyranose; Glc $p$, glucopyranose; Xylp, xylopyranose; Rhap, rhamnopyranose; Araf, arabinofuranose; ${ }^{\mathrm{b}}$ 2,3,6-Me $\mathrm{Me}_{3} \mathrm{Gal}-6-\mathrm{d}_{2}=1,4,5$-tri-O-acetyl-6,6-dideutero-2,3,6-tri-O-methyl-galactitol. c 2,3,4,6-Me4-Glc $=1,5$-di-O-acetyl-2,3,4,6-tetra-O-methyl-glucitol, etc. ${ }^{\mathrm{d}}$ Based on derived O-methylalditol acetates.

Most of the $\beta$-anomeric protons are in the $\delta 4-5 \mathrm{ppm}$ range while most of the $\alpha$-anomeric protons usually appear in the $\delta 5-6 \mathrm{ppm}$ region [16]. The resonances ranging from 4.8 to $5.24 \mathrm{ppm}$ in the ${ }^{1} \mathrm{H}-\mathrm{NMR}$ spectrum of HP (Figure 2A) revealed that the sugar residues of HP might be connected by $\beta$ - and $\alpha$-glycosidic bonds. The anomeric protons from each monosaccharide can give recognizable signals depending on their $\beta$ - or $\alpha$-configurations. The signal at $\delta 5.04,3.74,3.97,4.38$, and $4.68 \mathrm{ppm}$ was clearly assigned to $\mathrm{H}-1$ to $\mathrm{H}-5$ of $\alpha$-D-GalA residues, respectively. In a ${ }^{13} \mathrm{C}-\mathrm{NMR}$ spectrum, the signals derived from $\alpha$-anomeric carbons will appear in the range $\delta 95-101$ ppm while most of the $\beta$-anomeric carbons usually appear in the $8101-105 \mathrm{ppm}$ region [16]. The ${ }^{13} \mathrm{C}-\mathrm{NMR}$ spectrum of HP (Figure 2B) showed the anomeric peaks were centralized between $\delta 98.28$ and $\delta 105.06 \mathrm{ppm}$, indicating two kinds of anomeric configurations for monosaccharide residues of HP. The ${ }^{13} \mathrm{C}-\mathrm{NMR}$ spectrum showed characteristic anomeric signals at 899.7 , 103.1, and $104.4 \mathrm{ppm}$, which were due to the $\mathrm{C} 1$ resonances of 1,4- $\alpha$-D-GalA residues, $1,4-\beta-\mathrm{D}-\mathrm{Xylp}$ residues, and $1,4-\beta$-D-Glcp residues, at $\delta 105.5 \mathrm{ppm}$ due to the $\mathrm{C} 1$ resonances of $\beta$-D-Galp residues (Supplementary Materials Table S1). Other predominant signals at $\delta 70.9,71.4,80.5,73.4$, and $176.4 \mathrm{ppm}$ were related to $\mathrm{C}-2$ to $\mathrm{C}-6$ of $\alpha$-D-GalA residues, respectively. In addition, the signals at the low field from $\delta 160$ to $\delta 180 \mathrm{ppm}$ in the ${ }^{13} \mathrm{C}-\mathrm{NMR}$ spectrum of HP (Figure $2 \mathrm{~B}$ ) illustrated that the polysaccharide contained uronic acid [17]. All the NMR chemical shifts were compared with previously reported values $[18,19]$.

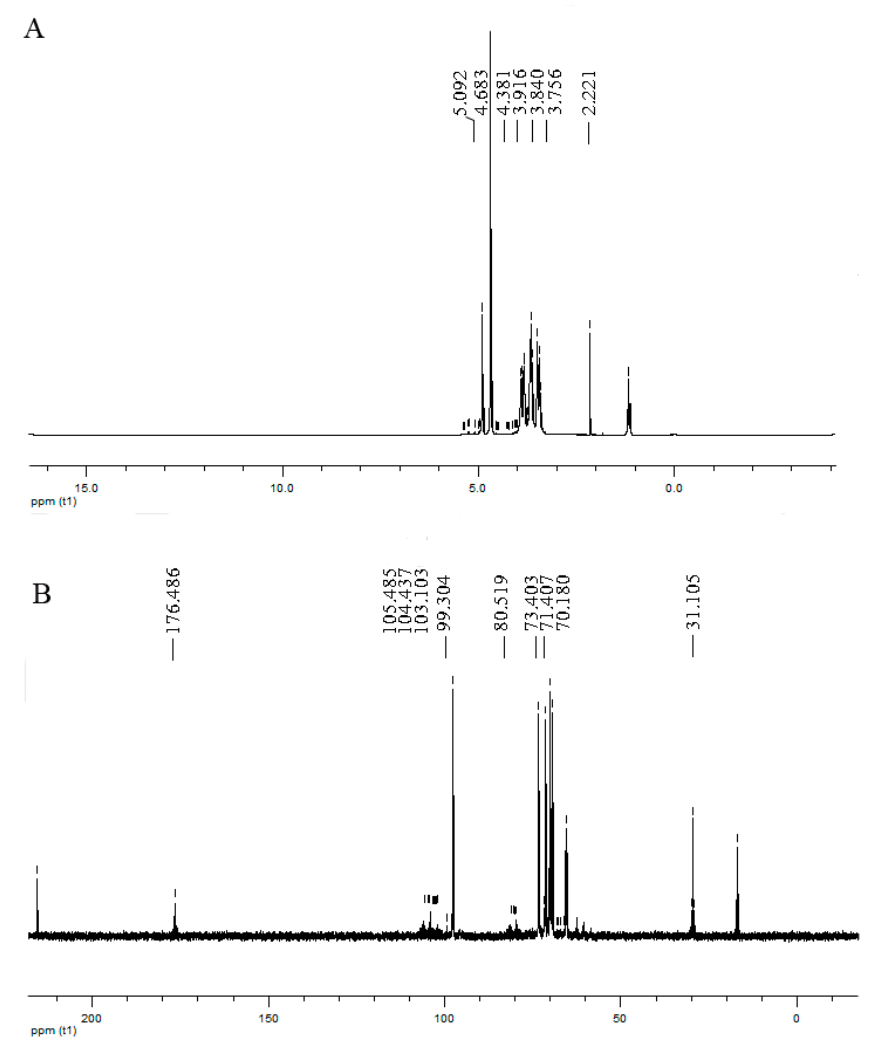

Figure 2. ${ }^{1} \mathrm{H}(\mathbf{A})$ and ${ }^{13} \mathrm{C}(\mathbf{B})$ nuclear magnetic resonance (NMR) spectra of $\mathrm{HP}$. 


\subsection{Cytotoxicity Assay}

The cytotoxicity assay was determined by calculating $\mathrm{CC}_{50}$. The effects of $H$. cordata extracts on the survival rate of the murine macrophage cell lines (RAW 264.7) are shown in Figure 3. Ethanol extract, HWE, and HP had no severe cytotoxicity effects towards RAW 264.7 cells with $\mathrm{CC}_{50}$ values $>500 \mu \mathrm{g} / \mathrm{mL}$ (Table 3). Therefore, at concentraetions $\leq 500 \mu \mathrm{g} / \mathrm{mL}$, the extracts would not affect the host cells in plaque assays.

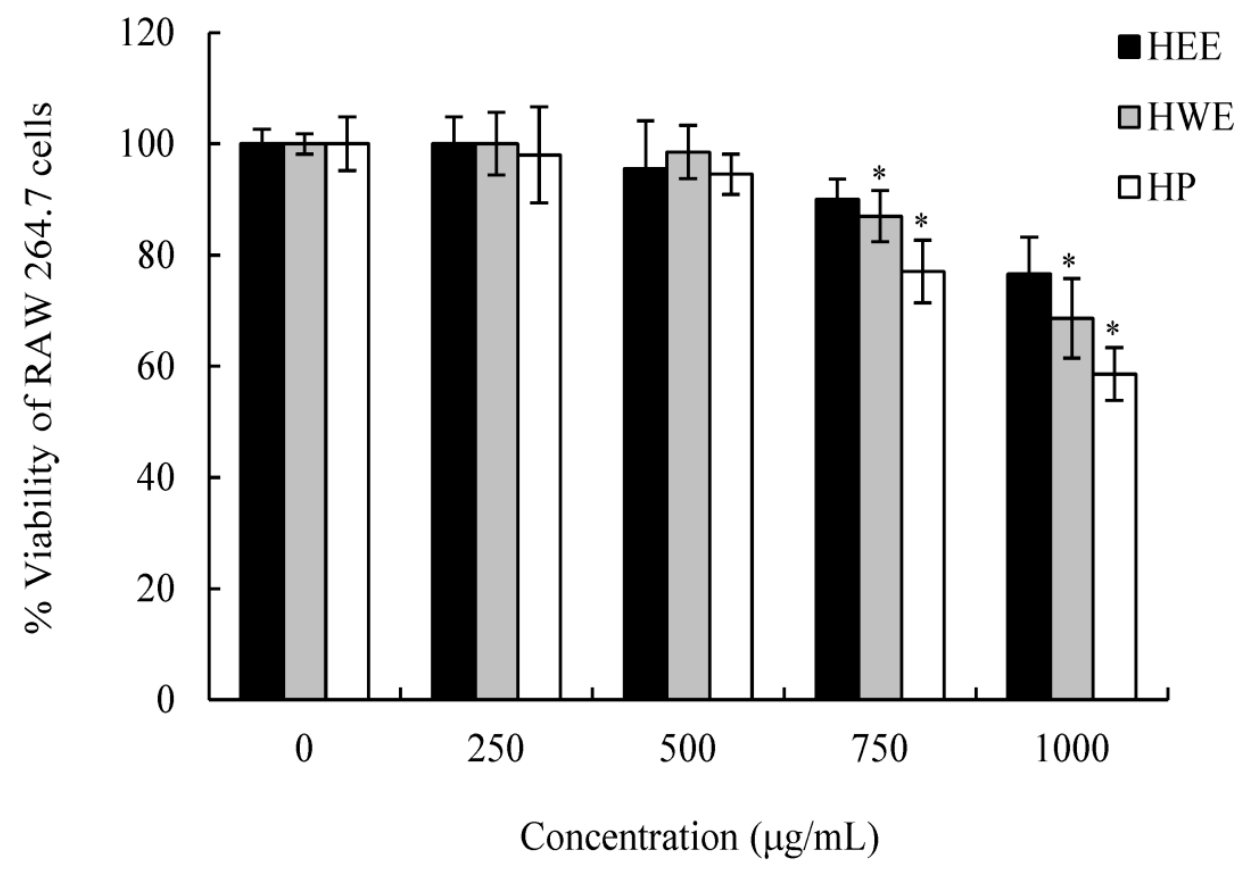

Figure 3. The effect of Houttuynia cordata extracts (HP, HCWE, and HCEE) 250, 500, 750, and $1000 \mu \mathrm{g} / \mathrm{mL}$ and phosphate-buffered saline (PBS) control $(0 \mu \mathrm{g} / \mathrm{mL})$ on the viability of the RAW 264.7 cell lines. Numbers are expressed as the \% viability of bacteria cells and the murine macrophage cells (RAW 264.7) remaining after 60 min incubation with Houttuynia cordata extracts. A higher number of surviving reflects the concentrations of Houttuynia cordata extracts would not affect the ability to use these host cells to determine anti-viral effects using plaque assays. Each experimental condition was analyzed in triplicate. All data were expressed as mean \pm standard deviation. Significant differences with HEE group are designated as ${ }^{*} p \leq 0.05$.

Table 3. Antiviral activities of $H$. cordata extracts against murine norovirus in RAW 264.7 cells using the mixed treatment assay.

\begin{tabular}{cccc}
\hline H. cordata Extracts & $\mathrm{CC}_{\mathbf{5 0}}(\mu \mathrm{g} / \mathrm{mL})^{\mathbf{a}}$ & $\mathrm{EC}_{\mathbf{5 0}}(\mu \mathrm{g} / \mathrm{mL})^{\mathbf{b}}$ & SI $^{\mathbf{c}}$ \\
\hline HEE & $2132.43 \pm 426.17$ & $1095.53 \pm 113.43$ & $1.95 \pm 0.84$ \\
HWE & $1237.52 \pm 367.65^{*}$ & $76.75 \pm 17.89 *$ & $16.14 \pm 3.81^{*}$ \\
HP & $1074.76 \pm 187.31^{*}$ & $187.24 \pm 77.82 *$ & $5.74 \pm 1.96^{*}$ \\
\hline
\end{tabular}

a $\mathrm{CC}_{50}$ : mean (50\%) value of cytotoxic concentration. ${ }^{\mathrm{b}} \mathrm{EC}_{50}$ : mean $(50 \%)$ value of effective concentration. c SI: selectivity index, $\mathrm{CC}_{50} / \mathrm{EC}_{50}$. Each experimental condition was analyzed in triplicate. Values are mean \pm standard deviation. Significant differences with HEE group are designated as ${ }^{*} p \leq 0.05$.

\subsection{Anti-Viral Activity of HP, HWE, and HEE}

We tested the dose-dependence of HP, HWE, and HEE on the reduction of viral titers (Table 4). The anti-noroviral activities of HP, HWE, and HEE were assessed by plaque assay (plaque forming units $(\mathrm{PFU}) / \mathrm{mL})$. H. cordata water extract (HWE) was assayed for its anti-viral activity on mouse norovirus 1 (MNV-1) at high $(8.09 \log 10 \mathrm{PFU} / \mathrm{mL})$ and $\operatorname{low}(4.38 \log 10 \mathrm{PFU} / \mathrm{mL})$ counts following incubation with different concentrations $(100,250$, and $500 \mu \mathrm{g} / \mathrm{mL}$ ) of HWE for $30 \mathrm{~min}$. When MNV-1 was treated with $100 \mu \mathrm{g} / \mathrm{mL}$ HWE, the viral titer was reduced. The amount of MNV-1 titer decreased by $1.38 \log 10 \mathrm{PFU} / \mathrm{mL}$ at high counts and by $1.87 \log 10 \mathrm{PFU} / \mathrm{mL}$ at low counts when compared to 
the untreated controls. At HWE $>250 \mu \mathrm{g} / \mathrm{mL}, \mathrm{MNV}-1$ titers decreased to undetectable level for low counts (4.38 $\log 10 \mathrm{PFU} / \mathrm{mL})$. Mouse norovirus 1 (MNV-1) was less sensitive to HP than HWE. At low counts, we obtained a greater reduction in viral titers with HP than at high counts. When MNV-1 was treated with $500 \mu \mathrm{g} / \mathrm{mL} \mathrm{HP}$, the infectivity of MNV-1 was decreased to undetectable levels in low counts. Anti-viral activity was also observed with HEE. At 100, 250, and $500 \mu \mathrm{g} / \mathrm{mL}$, HEE was effective in reducing MNV-1 titers in a dose-dependent manner when compared to the untreated controls. However, when HEE was used with high and low viral titers, we obtained less than $1 \log 10$ PFU/mL reduction in MNV-1 titer. The antiviral activity of $H$. cordata extracts was also evaluated by measuring $\mathrm{EC}_{50}$ (Table 3). Mean $\mathrm{EC}_{50}$ values were $187 \mu \mathrm{g} / \mathrm{mL}$ for HP, $76 \mu \mathrm{g} / \mathrm{mL}$ for HWE, and $1095 \mu \mathrm{g} / \mathrm{mL}$ for HEE. Mouse norovirus $1(\mathrm{MNV}-1)$ was more sensitive to HP and HWE than to HEE.

Table 4. Effects of HP, HWE, and HEE with low concentrations (4.38 log10 PFU/mL) and high concentrations (8.09 $\log 10 \mathrm{PFU} / \mathrm{mL}$ ) on mouse norovirus 1 (MNV-1) measured by plaque assay.

\begin{tabular}{|c|c|c|c|c|c|}
\hline \multirow{3}{*}{ Extracts } & \multirow{3}{*}{ Concentration } & \multicolumn{4}{|c|}{ MNV-1 (log10 PFU/mL) } \\
\hline & & \multicolumn{2}{|c|}{ Low Count $(4.38 \log 10)$} & \multicolumn{2}{|c|}{ High Count (8.09 $\log 10)$} \\
\hline & & Recovered Titer $^{c}$ & Reduction $^{\mathrm{e}}$ & Recovered Titer & Reduction \\
\hline PBS $^{\mathrm{a}}$ & $0 \mu \mathrm{g} / \mathrm{mL}$ & $4.38 \pm 1.71$ & 0 & $8.09 \pm 1.95$ & 0 \\
\hline $2 \mathrm{TU}^{\mathrm{b}}$ & $50 \mu \mathrm{M}$ & $2.50 \pm 0.83^{*}$ & 1.88 & $4.33 \pm 2.14 *$ & 3.76 \\
\hline \multirow[t]{3}{*}{$\mathrm{HP}$} & $100 \mu \mathrm{g} / \mathrm{mL}$ & $3.77 \pm 1.04$ & 0.61 & $7.49 \pm 2.53$ & 0.60 \\
\hline & $250 \mu \mathrm{g} / \mathrm{mL}$ & $2.62 \pm 1.03 *$ & 1.76 & $6.86 \pm 1.81 *$ & 1.23 \\
\hline & $500 \mu \mathrm{g} / \mathrm{mL}$ & $\mathrm{ND}^{* \mathrm{~d}}$ & 4.38 & $4.61 \pm 1.72 *$ & 3.48 \\
\hline \multirow[t]{3}{*}{ HWE } & $100 \mu \mathrm{g} / \mathrm{mL}$ & $2.51 \pm 0.53 *$ & 1.87 & $6.71 \pm 2.12 *$ & 1.38 \\
\hline & $250 \mu \mathrm{g} / \mathrm{mL}$ & $\mathrm{ND}^{*}$ & 4.38 & $6.26 \pm 1.32 *$ & 1.83 \\
\hline & $500 \mu \mathrm{g} / \mathrm{mL}$ & ND * & 4.38 & $3.96 \pm 0.74 *$ & 4.12 \\
\hline \multirow[t]{3}{*}{ HEE } & $100 \mu \mathrm{g} / \mathrm{mL}$ & $4.21 \pm 0.87$ & 0.16 & $8.03 \pm 2.89$ & 0.06 \\
\hline & $250 \mu \mathrm{g} / \mathrm{mL}$ & $3.48 \pm 1.33$ * & 0.90 & $7.52 \pm 1.73$ & 0.57 \\
\hline & $500 \mu \mathrm{g} / \mathrm{mL}$ & $3.24 \pm 0.41 *$ & 1.14 & $7.01 \pm 2.07 *$ & 0.98 \\
\hline
\end{tabular}

a,b Phosphate-buffered saline (PBS) was used as untreated control and 2-thiouridine (2TU) as a positive control.

${ }^{c}$ Values are mean \pm standard deviation. ${ }^{d}$ Not detected. ${ }^{e}$ Each titer was subtracted from the titer of the untreated sample (PBS). Each experimental condition was analyzed in triplicate. Significant differences with untreated control group are designated as ${ }^{*} p \leq 0.05$.

\subsection{Time-Dependence Experiment of HP, HWE, and HEE on Viral Count Reduction}

We tested the time-dependence of HP, HWE, and HEE on MNV-1 titer reduction. We incubated $250 \mu \mathrm{g} / \mathrm{mL} \mathrm{HP}, \mathrm{HWE}$, or HEE with high counts of MNV-1 for up to $60 \mathrm{~min}$ and measured the viral titers. As shown in Figure 4, MNV-1 titers in PBS (untreated control) did not appear to change during the 60-min exposure, while titers in $250 \mu \mathrm{g} / \mathrm{mL} \mathrm{HP}$ or HWE decreased significantly. The antiviral action of $\mathrm{HP}$ or HWE was rapid against MNV-1. Considerable changes (1.66 or $2.40 \log 10 \mathrm{PFU} / \mathrm{mL})$ in MNV-1 titers were obtained in the first 10 min following HP or HWE addition. The counts continued to drop by $1.74 \log 10 \mathrm{PFU} / \mathrm{mL}$ for HWE and $1.53 \log 10 \mathrm{PFU} / \mathrm{mL}$ for HP for the next $30 \mathrm{~min}$ and continued to drop for the following $30 \mathrm{~min}$. We obtained a total reduction in MNV-1 titers of $4.54 \log 10 \mathrm{PFU} / \mathrm{mL}$ for HWE and $3.69 \log 10 \mathrm{PFU} / \mathrm{mL}$ for HP. A time-dependence of the anti-viral activity of HEE on high titer MNV-1 was also observed. The viral titers of MNV-1 treated with HEE dropped slower in the first 30-40 min than HP and HWE and a total reduction in MNV-1 titers of $0.90 \log 10$ PFU/mL for HEE treatment were achieved. HWE and HP had stronger antiviral effects on MNV-1 than HEE. 


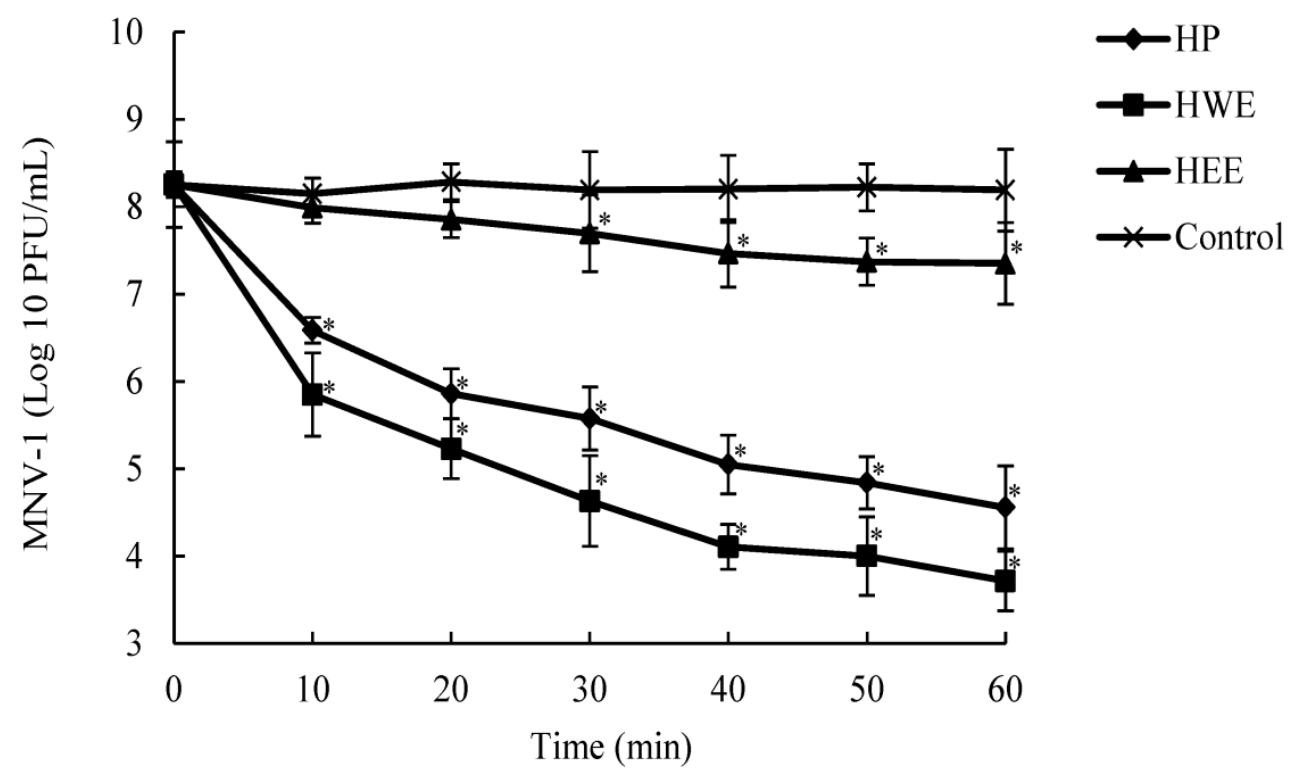

Figure 4. Change of MNV-1 titers versus incubation time after exposure to HP, HWE or HEE. Two-hundred-and-fifty $(\mu \mathrm{g} / \mathrm{mL})$ of $\mathrm{HP}$, HWE or HEE solutions were added to an equal volume of MNV-1 at titer of $\sim 8 \log 10 \mathrm{PFU} / \mathrm{mL}$ and incubated for up to $60 \mathrm{~min}$ at room temperature. The MNV-1 was recovered at $0,10,20,30,40,50$, and $60 \mathrm{~min}$ and assayed for its infectivity using standardized plaque assay. Each experimental condition was analyzed in triplicate. All data were expressed as mean \pm standard deviation. Significant differences with control group are designated as ${ }^{*} p \leq 0.05$.

\subsection{Viral Inactivation Kinetics}

Table 5 shows that there was a 4.34 - and 18.34 -fold decrease in $D$-values with 250 and $500 \mu \mathrm{g} / \mathrm{mL} \mathrm{HP}$, respectively, compared to $100 \mu \mathrm{g} / \mathrm{mL}$ HP. We obtained a 1.0-log reduction with $100 \mu \mathrm{g} / \mathrm{mL}$ HP-containing samples at $29.09 \mathrm{~min}$ and a 1.0-log reduction with $500 \mu \mathrm{g} / \mathrm{mL} \mathrm{HP-containing} \mathrm{samples} \mathrm{at} 1.59 \mathrm{~min}$.

Table 5. The Effect of HP with different concentrations on the D-values of MNV-1.

\begin{tabular}{cccccc}
\hline \multirow{2}{*}{$\mathbf{H P}(\boldsymbol{\mu} / \mathbf{m L})$} & \multicolumn{5}{c}{ Weibull Model Parameters $^{\mathbf{a}}$} \\
\cline { 2 - 6 } & $\boldsymbol{K} \pm \mathbf{S D}^{\mathbf{b}}$ & $\boldsymbol{\alpha} \pm \mathbf{S D}$ & $\boldsymbol{D}$-Value (min) $\pm \mathbf{S D}$ & $\mathbf{R M S E}$ & $\mathbf{R}^{\mathbf{2}}$ \\
\hline 100 & $0.144 \pm 0.65$ & $0.581 \pm 0.04$ & $28.098 \pm 2.44$ & 0.03 & 0.97 \\
250 & $0.213 \pm 0.01$ & $0.817 \pm 0.26$ & $6.647 \pm 0.93$ & 0.02 & 0.98 \\
500 & $0.866 \pm 0.08$ & $0.308 \pm 0.04$ & $1.597 \pm 0.31$ & 0.04 & 0.95 \\
\hline
\end{tabular}

${ }^{a} \mathrm{~K}$ is the characteristic time (h); $\alpha=$ shape parameter; $D$-value = storage time (day) required to reduce MNV-1 or Escherichia coli by 90\%; RMSE = correlation coefficient, a lower RMSE value indicates a better fit to the data; $\mathrm{R}^{2}=$ correlation coefficient, a higher $\mathrm{R}^{2}$ value indicate a better fit to the data. ${ }^{\mathrm{b}}$ Values are mean \pm standard deviation. Each experimental condition was analyzed in triplicate.

\subsection{Effect of HP on MNV-1 Viral Particles}

To further investigate the antiviral action of HP, the morphology of MNV-1 in low titer was analyzed by transmission electron microscopic (TEM) before and after treatment with PBS $(0 \mu \mathrm{g} / \mathrm{mL})$ and HP $(250 \mu \mathrm{g} / \mathrm{mL})$. Before treatment, MNV-1 particles were spherical (Figure $5 \mathrm{~A}$ ) and the size ranged from 30 to $35 \mathrm{~nm}$ as described previously [20]. After treatment with HP (250 $\mu \mathrm{g} / \mathrm{mL})$, the size of the MNV-1 particles increased to $80-100 \mathrm{~nm}$ in diameter. Additionally, we observed enlarged, denatured particles and disrupted particles (Figure 5B). The log 10 reductions of MNV-1 under these conditions were 2.75 with $250 \mu \mathrm{g} / \mathrm{mL}$ HP. These results suggest that HP denatures the viral capsid proteins, thereby preventing viral adhesion. 

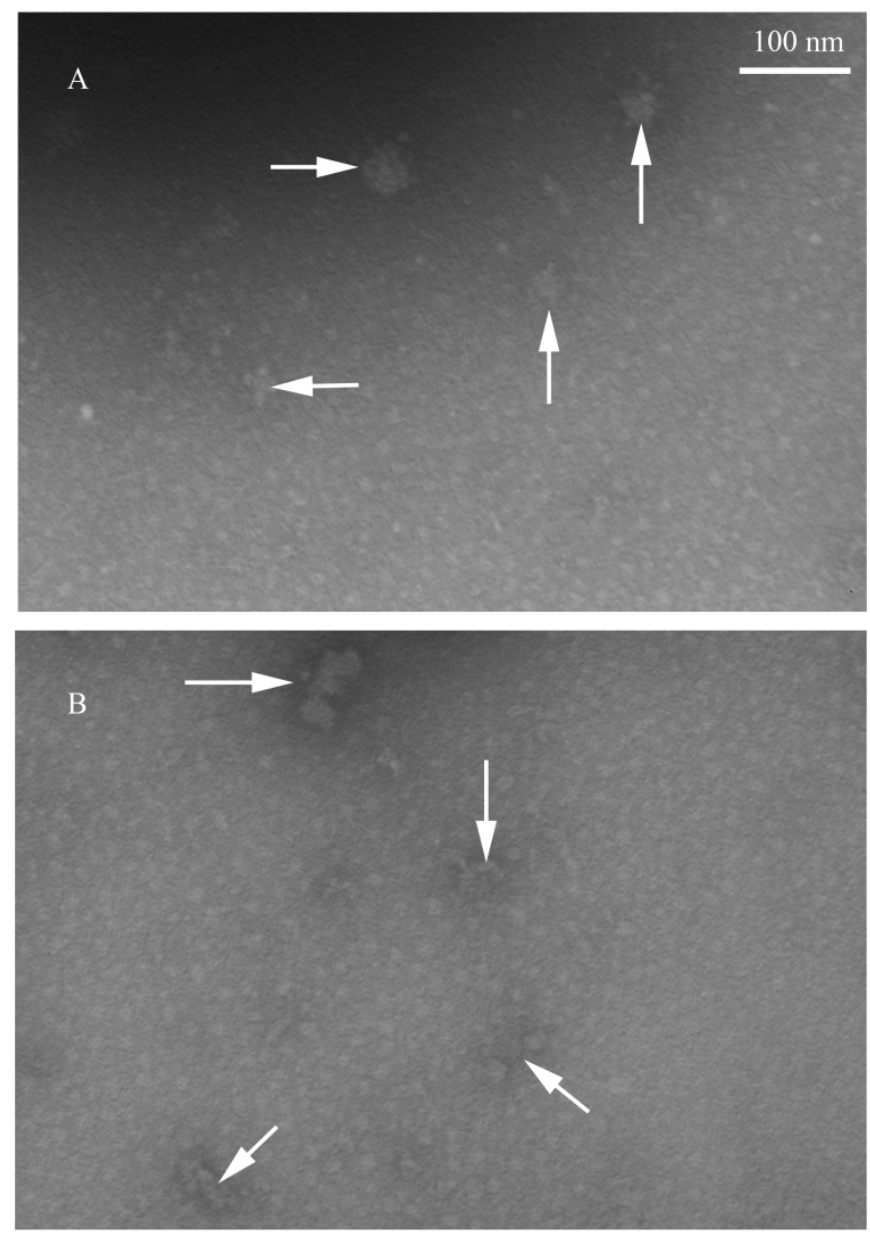

Figure 5. Transmission electron microscopic (TEM) images of MNV-1 in the absence or presence of HP. MNV-1 control (A) and MNV-1 treated with $250 \mu \mathrm{g} / \mathrm{mL}$ HP (B). Scale bars, $100 \mathrm{~nm}$.

\section{Discussion}

Although most studies have focused on investigating the role of $H$. cordata extracts against microorganisms [21,22], few studies have evaluated the effectiveness and mechanism of action of H. cordata extracts against HuNoVs. In this study, H. cordata extracts prepared in water (HWE and HP) and ethanol (HEE) exhibited various degrees of antiviral activity in a dose- and time-dependent manner. The values of selectivity index (SI) were 1.95 for HEE, 5.74 for HP, and 16.14 for HWE. Samples with high SIs had maximum antiviral activity, minimal cell toxicity, and a wider range of applications [23]. Among the extracts, HWE, mainly composed of carbohydrates, exhibited the strongest antiviral activity with the highest SI value. According to previous studies, carbohydrates are the main active substances in $H$. cordata water extracts and exhibited potent anti-viral activities $[1,2,6,12,13]$. In this study, we analyzed the $H$. cordata polysaccharide structures and their anti-noroviral mechanisms.

A polysaccharide (HP), isolated and purified from HWE with a molecular weight $<50 \mathrm{kDa}$, exhibited stronger anti-noroviral activity with higher SI value than HEE. Structural analysis revealed that HP mainly consists of $\alpha$-1,4-linked GalpA, $\beta$-1,4-linked Gal $p, \beta$-1,4-linked Glc $p$, and $\beta$-1,4-linked $\mathrm{Xyl} p$ residues. The predominant number of Gal $p$ and Gal $p$ A residues suggests that HP might be a pectin-like acidic polysaccharide with a 1,4-linked Gal $p$ core. In addition, 1, 6-linked Gal $p, 1,4,6$-linked Gal $p, 1,2,4$-linked Rhap, 1,5-linked Araf, and terminal-linked Gal $p$ and Glc $p$ in the side chains were detected. It has been proposed that some carbohydrates consisting of 1,4-linked GalpA may prevent the adhesion of some enteric pathogens such as protozoa, bacteria, and virus $[24,25]$. The polysaccharide (HP) is mainly composed of carbohydrates consisting of 1,4-linked GalpA and 1,4-linked Galp. 
The pectin-like acidic polysaccharide HP with a 1,4-linked Galp core might be the active substance in HWE responsible for the antiviral activity against MNV-1.

The Weibull model was used to evaluate the antiviral behavior of HP during $60 \mathrm{~min}$ (Supplementary Materials Figure S1). Based on the survival curves of MNV-1, the Weibull model showed the best fit to HP treatment with the highest $\mathrm{R}^{2}(>0.90)$ and lowest RMSE $(<0.05)$ values. The kinetic model for the inactivation of MNV-1 can be analyzed with the $D$-value, which represents the time required to reduce the population of pathogens by $90 \%$ and can be measured from a time versus $\log$ survivors' curve [26,27]. In our study, $D$-values decreased with increasing HP concentration. The $D$-values for MNV-1 inactivation were different $(p \leq 0.05)$ between the low treatments $(100 \mu \mathrm{g} / \mathrm{mL})$ and high treatments ( 250 and $500 \mu \mathrm{g} / \mathrm{mL}$ ).

To further understand the antiviral mechanism of $\mathrm{HP}$, we investigated the effects of $\mathrm{HP}$ on high-titer MNV-1 (8.09 $\log 10 \mathrm{PFU} / \mathrm{mL})$ using dose- and time-dependence experiments. Additionally, we observed the morphology of MNV-1 in low titer $(4.38 \log 10 \mathrm{PFU} / \mathrm{mL})$ with TEM under conditions that reduced its infectivity by more than $3 \log 10 \mathrm{PFU} / \mathrm{mL}$. It has been reported that some polysaccharides inhibit viral infections by blocking the adsorption, entry, and/or cell-to-cell transmission of viruses. In addition, polysaccharides bind to viral envelope glycoproteins and disrupt them with negatively charged carboxylate groups, therefore minimizing/preventing viruses from penetrating target cells [28,29]. In our study, the changes in size and morphology of MNV-1 particles following HP treatment demonstrated that the polysaccharide had anti-norovirus activity by denaturing and enlarging virus particles to inhibit virus penetration. The morphological changes in MNV-1 following HP treatment were similar to those obtained in bacteriophage T4 and rotavirus with flavonoid compound CJs (cranberry juices) [30] and in MNV-1 treated with polyphenolic compound RCS-F1 (raspberry seed extract fraction-1) [31]. These results suggest that these natural compounds inactivate viruses by a similar mechanism.

In this study, we identified the anti-norovirus potential of HWE, HP, and HEE using a plaque assay for MNV-1. The pectin-like acidic polysaccharide HP, with 1,4-linked Gal $p$ core, might be the active substance in HWE responsible for the antiviral activity against MNV-1. Currently, the only method for preventing noroviral infections is hand washing. In this study, the antiviral effects of HP and HWE reduced the residual MNV-1 infectivity following $10 \mathrm{~min}$ of incubation; therefore, these extracts interact immediately with the virus. The use of these extracts entails no safety concerns because $H$. cordata is a permitted food additive in China [32]. Our findings support the use of HP and HWE as nontoxic agents. Zhu et al. [33] and Kumar et al. [34] have shown that $H$. cordata exerts strong effects against a large number of enveloped and non-enveloped viruses. Therefore, HP and HWE might be potential antiviral agents in the prevention of viral diseases. However, we used unpurified HWE in this study. It is possible that total phenolics, proteins, and flavonoids in the extract may participate in the inactivation of the MNV-1 in a synergistic manner. It has been reported that a new type of flavonoid (Houttuynoids A-E (1-5)), from the whole plant of Houttuynia cordata, exhibited potent anti-HSV (herpes simplex viruses) activity [35]. The determination of the phenolic content in HWE through Folin-Ciocalteu solely corresponds to an estimation of the presence of reducing compounds in this study. Thus, future studies should investigate the characterization of polyphenolic profiles in HWE, and their mechanism of antiviral action.

\section{Materials and Methods}

\subsection{Preparation of HP, HWE, and HEE}

Houttuynia cordata was obtained from Zhejiang Chinese Medical University. Stems and leaves were air-dried at room temperature and ground (particle size $\leq 80$ mesh) using a Thomas-Willey milling machine (Thomas Willey Mills, Swedesboro, NJ, USA). To prepare HEE and HWE, we followed the method reported by Sekita [36], with some modifications. To prepare HEE, we heated H. cordata samples $(50 \mathrm{~g})$ in an electromagnetic cooker at $450 \mathrm{~W}$ for $10 \mathrm{~min}$, wrapped them in aluminum foil, 
and mixed them with $50 \mathrm{~mL}$ ethanol for $15 \mathrm{~min}$. Following centrifugation at $2000 \times \mathrm{g}$ for $15 \mathrm{~min}$, the supernatant was recovered, lyophilized, and stored at $4{ }^{\circ} \mathrm{C}$. To prepare $\mathrm{HWE}, \mathrm{H}$. cordata $(50 \mathrm{~g})$ was kept overnight at $16{ }^{\circ} \mathrm{C}$, immersed in $200 \mathrm{~mL}$ distilled water, and boiled under traditional reflux for $90 \mathrm{~min}$. After centrifugation at $2000 \times \mathrm{g}$ for $15 \mathrm{~min}$, the supernatant was recovered and concentrated under reduced pressure. Approximately $50 \mathrm{~mL}$ of concentrated extract was filtered, lyophilized, and stored at $4{ }^{\circ} \mathrm{C}$. $\mathrm{H}$. cordata polysaccharide (HP) was purified from HWE as previously reported [37]. Briefly, four volumes of $96 \%$ alcohol were added to HWE and stirred at room temperature. The precipitate was centrifuged at $8000 \mathrm{rpm}$ for $15 \mathrm{~min}$, washed several times with ethanol and acetone, and dried at room temperature. The purified polysaccharide obtained by DEAE chromatography $(2.5 \times 30 \mathrm{~cm}$, Bio-Rad, Richmond, CA, USA) was filtered through Sephacryl S-300 $(1.6 \times 100 \mathrm{~cm})$. The final fraction, labeled HP, was desalted and lyophilized. The homogeneity and molecular weight of HP were determined by HPLC (Waters, Alliance 2695 pump, Milford, MA, USA) coupled with a differential refractometer.

\subsection{Chemical Analysis}

The total carbohydrate content in H. cordata extracts was measured by the phenol-sulfuric acid method [37]. Phenolic compounds were expressed as mg of gallic acid/g (dry wt) of extract and tested by the Folin-Ciocalteu method. Protein was analyzed by the Lowry method. Uronic acid was measured by the $m$-hydroxydiphenyl method using galacturonic acid as the standard [38]. Total flavonoids were determined by the aluminum chloride method and expressed as mg of rutin equivalents (RE) per gram of extract [39]. In addition, monosaccharide composition was measured by 1-phenyl-3-methyl-5-pyrazolone (PMP)-HPLC [40]. Infrared spectra of HP were determined using $\mathrm{KBr}$ disk method and recorded at $400-4000 \mathrm{~cm}^{-1}$.

Methylation analysis was performed as previously reported [37]. Hydroxyl groups were methylated using lithium dimethylsulfonyl as anion and confirmed by FTIR spectroscopy. Methyl esters of uronic acids were reduced by lithium triethylborodeuteride (Superdeuteride ${ }^{\circledR}$, Aldrich, Milwaukee, WI, USA) [38]. Methylated polysaccharides were subsequently hydrolyzed with $2 \mathrm{M}$ trifluoroacetic acid for $2 \mathrm{~h}$ at $120^{\circ} \mathrm{C}$. Prior to analysis, the derivatives were reduced by NaBD4 and acetylated with acetic anhydride (Ac2O) and 1-methylimidazole (1-MeIm). Gas chromatography-mass spectrometry (GC/MS) was performed using an HP-5890 system coupled to an OV1701 column $(0.25 \mathrm{~mm} \times 30 \mathrm{~m})$ and a temperature program ranging from $140{ }^{\circ} \mathrm{C}$ to $280^{\circ} \mathrm{C}$ at $3{ }^{\circ} \mathrm{C} / \mathrm{min}$. The quantification of alditol acetate was carried out by the response factor and peak area of FID in GC. For nuclear magnetic resonance (NMR) analysis, the purified HP $(60 \mathrm{mg} / \mathrm{mL})$ was deuterium-exchanged by freeze-drying three times and then dissolved in $0.5 \mathrm{~mL}$ of $99 \% \mathrm{D}_{2} \mathrm{O}$. The spectra were recorded by a $500-\mathrm{MHz}$ Bruker Avance 500 spectrometer for ${ }^{1} \mathrm{H}$ and $125 \mathrm{MHz}$ for ${ }^{13} \mathrm{C}$ [41]. Signals at $\delta \mathrm{H} 2.22$ and $\delta \mathrm{C} 31.1$ for acetone were used as external standards.

\subsection{Propagation of Viruses}

Murine norovirus-1 and RAW264.7 cells were obtained from American Type Culture Collection (ATCC). Murine norovirus-1 propagation was performed by inoculation of confluent monolayers of RAW 267.4 cells. The RAW 264.7 cells were grown at $37^{\circ} \mathrm{C}$ in a $5 \% \mathrm{CO}_{2}$ atmosphere in Dulbecco's modified Eagle medium (DMEM) supplemented with 10\% heat inactivated 1× Anti-Anti (Gibco, Grand Island, NY, USA) and fetal bovine serum (FBS). Stocks of MNV-1 were prepared and stored at $-70{ }^{\circ} \mathrm{C}[42,43]$.

\subsection{Antiviral Effects of HP, HWE, and HEE}

Ten-fold serial dilution of filter-sterilized H. cordata extracts (HP, HWE, and HEE) were used to determine cytotoxicity. Cytopathic effects were assessed by visual inspection after $3 \mathrm{~d}$ of incubation [44]. The cytotoxicity and virus-induced cytopathic effects were measured by MTT (3-[4, 5-dimethylthiazol-2-yl]-2, 5 diphenyl tetrazolium bromide) assay [45]. The 50\% cytotoxicity 
concentration $\left(\mathrm{CC}_{50}\right)$ value was determined following a 24-h treatment of RAW 264.7 cell monolayers to different doses of $H$. cordata extracts $[18,45]$. H. cordata extracts (HP, HWE, and HEE) were dissolved in sterile PBS at concentrations of $3000 \mu \mathrm{g} / \mathrm{mL}$, sterilized by filtration $(0.2-\mu \mathrm{m}$ pore-size membrane), and diluted aseptically to 200,500,1000, 1500, and $2000 \mu \mathrm{g} / \mathrm{mL}$ in sterile PBS. To evaluate dose dependence, an equal volume of HP, HWE or HEE was added to an equal volume of MNV-1 resulting in titers of $8.09 \log 10 \mathrm{PFU} / \mathrm{mL}$ or $4.38 \log 10 \mathrm{PFU} / \mathrm{mL}$ and incubated for $30 \mathrm{~min}$ at room temperature. In this study, the $50 \%$ effective concentration $\left(\mathrm{EC}_{50}\right)$ value was considered to be the concentration of $H$. cordata extracts required to reach only $50 \%$ of cytopathogenic effects caused by the MNV-1. Selectivity index was determined by the effectiveness at inhibiting MNV-1-induced cell death $\left(\mathrm{CC}_{50} / \mathrm{EC}_{50}\right)$ [45]. For an analysis of time dependence, a set concentration $(250 \mu \mathrm{g} / \mathrm{mL}) \mathrm{of} \mathrm{HP}, \mathrm{HWE}$ or HEE was added to an equal volume of MNV-1 and incubated for 0, 10, 20, 30, 40, 50 or 60 min at room temperature. 2-thiouridine was used as a positive control. For the untreated control, we used individual viruses mixed with PBS. Following incubation, the reaction in each mixture was terminated with the addition of PBS.

\subsection{Plaque Assay}

Infectivity of MNV-1 was determined by the standardized plaque assay [10]. The RAW 264.7 cells were plated in 6-well plates at $2 \times 10^{6}$ cells per well and grown until reaching $85 \%$ to $90 \%$ confluency. Serial ten-fold diluted viral strains were prepared in DMEM supplemented with 10\% FBS. The viral dilution $(0.5 \mathrm{~mL})$ was inoculated into each well after aspiration of the media and incubated at $37^{\circ} \mathrm{C}$ for $2.5 \mathrm{~h}$. Following viral adsorption, the supernatant was removed and replaced with fresh DMEM (2 mL) containing $1 \%$ penicillin-streptomycin, $0.75 \%$ agarose, and 10\% FBS. After $72 \mathrm{~h}$ of incubation, plates were overlaid with media containing $0.02 \%$ neutral red. Finally, plaques were calculated following incubation for $5 \mathrm{~h}$ at $37^{\circ} \mathrm{C}$. Titer reductions were measured by subtracting the titer of the samples from the titer of the PBS control.

\subsection{Transmission Electron Microscopy (TEM)}

Three-microliter aliquots of MNV-1 suspensions with $H$. cordata polysaccharide HP were diluted 10 -fold in water and placed on a carbon-coated electron microscopy (EM) grid. The viral samples were stained with $3 \%$ aqueous uranyl acetate $(3 \mu \mathrm{L})$ for approximately $1 \mathrm{~min}$, air-dried, and observed under a JEOL-1400 electron microscope (Jeol, Tokyo, Japan) at $80 \mathrm{kV}$. Images were captured with a Gatan UltraScan 1000 XP camera (Gatan, Pleasanton, CA, USA) at a magnification of $\times 40,000$ [46].

\subsection{Viral Inactivation Kinetics}

Viral inactivation kinetics were determined as previously described [26], with a slight modification. Briefly, HP solutions were prepared in PBS at 0, 100, 250, and $500 \mu \mathrm{g} / \mathrm{mL}$ HP. The polysaccharide $(100 \mu \mathrm{L})$ was added to an equal volume of MNV-1. Following incubation for 0, 5, 10, 20, 30, and 60 min at room temperature, viral counts were measured by calculating the PFU titers. All experiments were carried out in triplicate. The decimal reduction time ( $D$-value) was measured as previously reported [27] with slight modifications. The non-linear model (Weibull) can be expressed as Equations (1) and (2) [27].

$$
\begin{gathered}
\log _{10}\left(\frac{N}{N_{0}}\right)=-K t^{\alpha} \\
D=\left(\frac{1}{K}\right)^{\frac{1}{\alpha}}
\end{gathered}
$$

where $\alpha$ is the shape parameter, $K$ is the characteristic time (min), and $D$ is the time required to reduce the population of pathogens by $90 \%$. The model-fitting ability was assessed by measuring the root mean squared error (RMSE) and the coefficient of determination $\left(\mathrm{R}^{2}\right)$. To estimate the viral inactivation kinetics, the model was fitted using non-linear regression by Microsoft Excel 2013. 


\subsection{Statistical Analyses}

Data were analyzed by Student's $t$-test using the SPSS program. All experiments were carried out three times. Data were expressed as mean \pm SE. Statistical significance was set at $p \leq 0.05$.

Supplementary Materials: The Supplementary Materials are available online.

Author Contributions: Conceptualization, N.L. and R.Z.; methodology, D.C.; software, L.S.; validation, H.M. and S.Z.; formal analysis, J.C.; investigation, Y.Z. resources, Y.Z. data curation, S.Z.; writing-original draft preparation, N.L.; writing-review and editing, N.L.; supervision, R.Z.; project administration, N.L.; funding acquisition, R.Z.

Funding: This research was sponsored by the National Natural Science Foundation of China (\# 31301715), the National Science and Technology Major Project (\#2018ZX10734401) and the Program of Health and Medicine Science in Zhejiang Province (NO. 2017KY292).

Acknowledgments: The authors express their thanks to Ran Cai for sample analysis. Technical assistance of Xiuyu Lou and Liming Gong are also gratefully acknowledged.

Conflicts of Interest: The authors declare no conflict of interest.

$\begin{array}{ll}\text { Abbreviations } \\ \text { HP } & \text { Houttuynia cordata polysaccharide } \\ \text { HWE } & \text { Houttuynia cordata water extract } \\ \text { HEE } & \text { Houttuynia cordata ethanol extract } \\ \text { GlaUA } & \text { galacturonic acid } \\ \text { Gal } & \text { galactose } \\ \text { Rha } & \text { rhamnose } \\ \text { Ara } & \text { arabinose } \\ \text { GluA } & \text { glucuronic acid } \\ \text { Glc } & \text { glucose } \\ \text { Man } & \text { mannose } \\ \text { Xyl } & \text { xylose } \\ \text { HuNoV } & \text { Human norovirus } \\ \text { MNV-1 } & \text { murine norovirus-1 } \\ \text { ATCC } & \text { American Type Culture Collection } \\ \text { PFU } & \text { Plaque forming units }\end{array}$

\section{References}

1. Yang, L.; Jiang, J.G. Bioactive components and functional properties of Hottuynia cordata and its applications. Pharm. Biol. 2009, 47, 1154-1161. [CrossRef]

2. Hayashi, K.; Kamiya, M.; Hayashi, T. Virucidal effects of the steam distillate from Houttuynia cordata and its components on HSV-1, influenza virus, and HIV. Planta Med. 1995, 61, 237-241. [CrossRef]

3. Karst, S.M.; Wobus, C.E.; Goodfellow, I.G.; Green, K.Y.; Virgin, H.W. Advances in norovirus biology. Cell Host Microbe 2014, 15, 668-680. [CrossRef]

4. Jones, M.K.; Grau, K.R.; Costantini, V.; Kolawole, A.O.; De Graaf, M.; Freiden, P.; Graves, C.L.; Koopmans, M.; Wallet, S.M.; Tibbetts, S.A.; et al. Human norovirus culture in B cells. Nat. Protoc. 2015, 10, 1939-1942. [CrossRef]

5. Li, D.; Baert, L.; Uyttendaele, M. Inactivation of food-borne viruses using natural biochemical substances. Food Microbiol. 2013, 35, 1-9. [CrossRef] [PubMed]

6. Li, T.; Peng, T. Traditional Chinese herbal medicine as a source of molecules with antiviral activity. Antivir. Res. 2013, 97, 1-9. [CrossRef] [PubMed]

7. Zakay-Rones, Z.; Thom, E.; Wollan, T.; Wadstein, J. Randomized study of the efficacy and safety of oral elderberry extract in the treatment of influenza A and B virus infections. J. Int. Med. Res. 2004, 32, 132-140. [CrossRef]

8. Cowan, M.M. Plant products as antimicrobial agents. Clin. Microbial. Rev. 1999, 12, 564-582. [CrossRef]

9. Yang, M.; Lee, G.; Si, J.; Lee, S.J.; You, H.J.; Ko, G. Curcumin shows antiviral properties against norovirus. Molecules 2016, 21, 1401. [CrossRef] [PubMed] 
10. Wobus, C.E.; Thackray, L.B.; Virgin, H.W. Murine norovirus: A model system to study norovirus biology and pathogenesis. J. Virol. 2006, 80, 5104-5112. [CrossRef]

11. Wang, D.; Tian, P. Inactivation conditions for human norovirus measured by an in situ capture-qRT-PCR method. Int. J. Food Microbiol. 2014, 172, 76-82. [CrossRef]

12. Tian, L.; Zhao, Y.; Guo, C.; Yang, X. A comparative study on the antioxidant activities of an acidic polysaccharide and various solvent extracts derived from herbal Houttuynia cordata. Carbohydr. Polym. 2011, 83, 537-544. [CrossRef]

13. Cheng, B.H.; Chan, J.Y.W.; Chan, B.C.L.; Lin, H.Q.; Han, X.Q.; Zhou, X.; Wan, D.C.C.; Wang, Y.F.; Leung, P.C.; Fung, K.P.; et al. Structural characterization and immunomodulatory effect of a polysaccharide HCP-2 from Houttuynia cordata. Carbohydr. Polym. 2014, 103, 244-249. [CrossRef]

14. Kafle, K.; Park, Y.B.; Lee, C.M.; Stapleton, J.J.; Kiemle, S.N.; Cosgrove, D.J.; Kim, S.H. Effects of mechanical stretching on average orientation of cellulose and pectin in onion epidermis cell wall: A polarized FT-IR study. Cellulose 2017, 24, 3145-3154. [CrossRef]

15. Shakhmatov, E.G.; Udoratina, E.V.; Atukmaev, K.V.; Makarova, E.N. Extraction and structural characteristics of pectic polysaccharides from Abies sibirica L. Carbohydr. Polym. 2015, 123, 228-236. [CrossRef] [PubMed]

16. Cui, S.W. Food Carbohydrates: Chemistry, Physical Properties, and Applications; CRC Press: Boca Raton, FL, USA, 2005.

17. Acharya, D.; Mitaine-Offer, A.C.; Kaushik, N.; Miyamoto, T.; Paululat, T.; Lacaille-Dubois, M.A. Furostane-Type Steroidal Saponins from the Roots of Chlorophytum borivilianum. Helv. Chim. Acta 2008, 91, 2262-2269. [CrossRef]

18. Fan, J.; Zhang, J.; Tang, Q.; Liu, Y.; Zhang, A.; Pan, Y. Structural elucidation of a neutral fucogalactan from the mycelium of Coprinus comatus. Carbohydr. Res. 2006, 341, 1130-1134. [CrossRef]

19. Habibi, Y.; Mahrouz, M.; Vignon, M.R. Isolation and structural characterization of protopectin from the skin of Opuntia ficus-indica prickly pear fruits. Carbohydr. Polym. 2005, 60, 205-213. [CrossRef]

20. Lee, E.J.; Lee, W.; Kim, M.; Choi, E.H.; Kim, Y.J. Arc discharge-mediated disassembly of viral particles in water. Water Res. 2016, 102, 305-312. [CrossRef]

21. Kang, C.G.; Hah, D.S.; Kim, C.H.; Kim, Y.H.; Kim, E.; Kim, J.S. Evaluation of antimicrobial activity of the methanol extracts from 8 traditional medicinal plants. Toxicol. Res. 2011, 27, 31-38. [CrossRef] [PubMed]

22. Li, T.; Liu, L.; Wu, H.; Chen, S.; Zhu, Q.; Gao, H.; Yu, X.; Wang, Y.; Su, W.; Yao, X.; et al. Anti-herpes simplex virus type 1 activity of Houttuynoid A, a flavonoid from Houttuynia cordata Thunb. Antivir. Res. 2017, 144, 273-280. [CrossRef]

23. Eom, S.H.; Moon, S.Y.; Lee, D.S.; Kim, H.J.; Park, K.; Lee, E.W.; Kim, T.H.; Chung, Y.H.; Lee, M.S.; Kim, Y.M. In vitro antiviral activity of dieckol and phlorofucofuroeckol-A isolated from edible brown alga Eisenia bicyclis against murine norovirus. Algae 2015, 30, 241-248. [CrossRef]

24. Józefiak, D.; Rutkowski, A.; Martin, S.A. Carbohydrate fermentation in the avian ceca: A review. Anim. Feed Sci. Tech. 2004, 113, 1-15. [CrossRef]

25. Ferrazzano, G.; Amato, I.; Ingenito, A.; Zarrelli, A.; Pinto, G.; Pollio, A. Plant polyphenols and their anti-cariogenic properties: A review. Molecules 2011, 16, 1486-1507. [CrossRef]

26. Seo, K.; Lee, J.E.; Lim, M.Y.; Ko, G. Effect of temperature, $\mathrm{pH}$, and $\mathrm{NaCl}$ on the inactivation kinetics of murine norovirus. J. Food Prot. 2012, 75, 533-540. [CrossRef]

27. Bozkurt, H.; D'Souza, D.H.; Davidson, P.M. A comparison of the thermal inactivation kinetics of human norovirus surrogates and hepatitis A virus in buffered cell culture medium. Food Microbiol. 2014, 42, 212-217. [CrossRef] [PubMed]

28. Damonte, E.B.; Matulewicz, M.C.; Cerezo, A.S. Sulfated seaweed polysaccharides as antiviral agents. Curr. Med. Chem. 2004, 11, 2399-2419. [CrossRef]

29. Shi, Q.; Wang, A.; Lu, Z.; Qin, C.; Hu, J.; Yin, J. Overview on the antiviral activities and mechanisms of marine polysaccharides from seaweeds. Carbohydr. Res. 2017, 453, 1-9. [CrossRef]

30. Lipson, S.M.; Sethi, L.; Cohen, P.; Gordon, R.E.; Tan, I.P.; Burdowski, A.; Stotzky, G. Antiviral effects on bacteriophages and rotavirus by cranberry juice. Phytomedicine 2007, 14, 23-30. [CrossRef]

31. Lee, J.H.; Bae, S.Y.; Oh, M.; Seok, J.H.; Kim, S.; Chung, Y.B.; Gowda, K.G.; Mun, J.Y.; Chung, M.S.; Kim, K.H. Antiviral effects of black raspberry (Rubus coreanus) seed extract and its polyphenolic compounds on norovirus surrogates. Biosci. Biotechnol. Biochem. 2016, 80, 1196-1204. [CrossRef] 
32. Pang, J.; Dong, W.; Li, Y.; Xia, X.; Liu, Z.; Hao, H.; Jiang, L.; Liu, Y. Purification of houttuynia cordata thunb. essential oil using macroporous resin followed by microemulsion encapsulation to improve its safety and antiviral activity. Molecules 2017, 22, 293. [CrossRef] [PubMed]

33. Zhu, H.; Lu, X.; Ling, L.; Li, H.; Ou, Y.; Shi, X.; Lu, Y.; Zhang, Y.; Chen, D. Houttuynia cordata polysaccharides ameliorate pneumonia severity and intestinal injury in mice with influenza virus infection. J. Ethnopharmacol. 2018, 218, 90-99. [CrossRef]

34. Kumar, M.; Prasad, S.K.; Hemalatha, S. A current update on the phytopharmacological aspects of Houttuynia cordata Thunb. Pharmacogn. Rev. 2014, 8, 22-35. [PubMed]

35. Chen, S.D.; Gao, H.; Zhu, Q.C.; Wang, Y.Q.; Li, T.; Mu, Z.Q.; Wu, H.L.; Peng, T.; Yao, X.S. Houttuynoids A-E, anti-herpes simplex virus active flavonoids with novel skeletons from Houttuynia cordata. Org. Lett. 2012, 14, 1772-1775. [CrossRef] [PubMed]

36. Sekita, Y.; Murakami, K.; Yumoto, H.; Mizuguchi, H.; Amoh, T.; Ogino, S.; Matsuo, T.; Miyake, Y.; Fukui, H.; Kashiwada, Y. Anti-bacterial and anti-inflammatory effects of ethanol extract from Houttuynia cordata poultice. Biosci. Biotechnol. Biochem. 2016, 80, 1205-1213. [CrossRef] [PubMed]

37. Liao, N.; Sun, L.; Chen, J.; Zhong, J.; Zhang, Y.; Zhang, R. A novel polysaccharide conjugate from bullacta exarata induces G1-phase arrest and apoptosis in human hepatocellular carcinoma HepG2 cells. Molecules 2017, 22, 384. [CrossRef]

38. Chen, X.; Song, L.; Wang, H.; Liu, S.; Yu, H.; Wang, X.; Li, R.; Liu, T.; Li, P. Partial Characterization, the Immune Modulation and Anticancer Activities of Sulfated Polysaccharides from Filamentous Microalgae Tribonema sp. Molecules 2019, 24, 322. [CrossRef] [PubMed]

39. Vu, B.; Chen, M.; Crawford, R.; Ivanova, E. Bacterial extracellular polysaccharides involved in biofilm formation. Molecules 2009, 14, 2535-2554. [CrossRef]

40. Karimi, E.; Oskoueian, E.; Hendra, R.; Jaafar, H.Z. Evaluation of Crocus sativus L. stigma phenolic and flavonoid compounds and its antioxidant activity. Molecules 2010, 15, 6244-6256. [CrossRef]

41. Liu, D.; Liao, N.; Ye, X.; Hu, Y.; Wu, D.; Guo, X.; Zhong, J.; Wu, J.; Chen, S. Isolation and structural characterization of a novel antioxidant mannoglucan from a marine bubble snail, Bullacta exarata (Philippi). Mar. Drugs 2013, 11, 4464-4477. [CrossRef]

42. Julian, T.R.; Trumble, J.M.; Schwab, K.J. Evaluating efficacy of field-generated electrochemical oxidants on disinfection of fomites using bacteriophage MS2 and mouse norovirus MNV-1 as pathogenic virus surrogates. Food Environ. Virol. 2014, 6, 145-155. [CrossRef] [PubMed]

43. Bae, J.; Schwab, K.J. Evaluation of murine norovirus, feline calicivirus, poliovirus, and MS2 as surrogates for human norovirus in a model of viral persistence in surface water and groundwater. Appl. Environ. Microb. 2008, 74, 477-484. [CrossRef] [PubMed]

44. Su, X.; Sangster, M.Y.; D'Souza, D.H. In vitro effects of pomegranate juice and pomegranate polyphenols on foodborne viral surrogates. Foodborne Pathog. Dis. 2010, 7, 1473-1479. [CrossRef] [PubMed]

45. Szliszka, E.; Skaba, D.; Czuba, Z.P.; Krol, W. Inhibition of inflammatory mediators by neobavaisoflavone in activated RAW264.7 macrophages. Molecules 2011, 16, 3701-3712. [CrossRef] [PubMed]

46. Hermelink, A.; Naumann, D.; Piesker, J.; Lasch, P.; Laue, M.; Hermann, P. Towards a correlative approach for characterising single virus particles by transmission electron microscopy and nanoscale Raman spectroscopy. Analyst 2017, 142, 1342-1349. [CrossRef]

Sample Availability: Not Available. 